are almost suicidal." Fears that black children will be drugged against their will are unfounded, he said, because it is mostly affluent white families that have access to this treatment.

But Garland Allen, a biologist at Washington University, said, "Sometimes it is normal to react violently in a repressive situation. By treating behavioural problems with drugs, we ignore the other components."

However, David Goldman, a neurobiologist at the National Institute of Alcoholism and Alcohol Abuse, warned that some individuals who display antisocial and violent behaviour may in fact have underlying pathological conditions. "If you put a stop to studying the neurobiology of antisocial behaviour, you may also stop research into many pathological conditions that are manifested by this behaviour," he said. "Neither the genome nor the brain is conveniently divided into politically correct and incorrect regions."

Already, researchers are finding single genes associated with complex behaviours. "Many people are unwilling to face the fact that there are genetic influences on behaviour," said Goldman. "Unfortunately it's a fact that is not going to go away."

Whether any consensus was reached is doubtful. "If you asked scientists to agree on the components of lemonade, they would fight it out," said Carey. "They would divide themselves into the waterists, sugarists and lemonists. They would hold meetings and hash it out. But all empirical data suggest it is lemonade - an inextricable combination of lemon, water and sugar."

Most people attending the conference would probably agree that criminal behaviour results from a combination of well-melded key ingredients. But whether some researchers place too much emphasis on the genetic and physiological factors - or whether critics are too quick to dismiss their role - is a question that is unlikely to be resolved any time soon. The research, once released into the public domain, is often subject to misuse and misinterpretation by both the public at large and policy makers, and this is what many in the field find most frightening.

"Genetic determinism is alive and well," said Paul Billings of Stanford University in Palo Alto, California. "We have a eugenic history in this country that we're not proud of. And there is little evidence that the bad old days are really over."

NANCY TOUCHETTE Baltimore

\title{
UK insurers seek a genetic code
}

In a rapid change of strategy, Britain's insurance industry is holding discussions with clinical geneticists, molecular biologists and others in genetic medicine, on a code of practice covering the use of genetic information in assessing individuals for life insurance. The move results from a recommendation by a parliamentary committee, in a report published in July, that if the industry fails to come up with a satisfactory code of practice within the next 12 months, the government should step in with legislation. A voluntary code is seen by the industry as the lesser of two evils, particularly in view of the fact that several European countries such as Denmark and the Netherlands have already banned the use of genetic information by insurance companies altogether.

Indeed, the industry's new-found readiness to enter into discussions on such a code has been generally welcomed by those who have been calling for tougher action to prevent the possible abuse of genetic information by the insurance industry. The committees report has certainly had a galvanizing effect on the industry, says David Shapiro, executive secretary of the Nuffield Council on Bioethics. At the same time, some critics argue that, by restricting attention to the question of life insurance, the current talks risk diverting attention away from broader issues, such as the dangers of general discrimination against those who are shown by screening to be susceptible to genetic-related disorders.

The rapidity of the shift in the insurance industry's position is evident from a comparison between its current position and that which members of the Association of British Insurers espoused when they appeared in January before the House of Commons Select Committee on Science and Technology, at hearings on human genetics. At that meeting, Roger Bowley presented a strong case that in industry's view new regulation was unnecessary. He argued, for example, that the industry had no plans to require genetic testing of those seeking life insurance coverage, but that any restrictions on its ability to use genetic information already available in calculating premiums would inevitably discriminate against normal policy holders by requiring them to pay higher premiums than would be the case if genetic data revealed them to be relatively 'healthy'.
Bowley warned that, even if the use of genetic information was not banned, excessively rigid controls on the circumstances in which it could be used could reduce the ability of British companies to compete in the increasingly international insurance market against companies in other countries with less restrictive operating conditions. He also admitted that if the industry was required to spread across all policy holders the cost of providing life insurance for the five percent of individuals who are currently denied such cover because of their medical condition, premiums could increase by two or three times.

But the association's defensive stance did not go down well with Members of Parliament. In particular, MPs on the committee expressed concern that fears of being asked to pay a higher premium for insurance coverage could dissuade individuals from volunteering for genetic screening which might be helpful.

Despite assurances that the industry had been in close contact with individual clinical geneticists and other medical professionals, the committee heard immediately afterward from Peter Harper, chair of the clinical genetics committee of the Royal College of Physicians, that he had been trying unsuccessfully for three years to engage the industry in serious discussion of the issue with professional medical bodies or their representatives. Harper expressed concern that the industry still considers the use of genetic test information as no different from other medical information.

Accepting the industry's own preference for self-regulation, the committee proposes that it be given one year in which to propose a solution acceptable to Parliament. If it fails to do so, a solution should be sought, by legislation if necessary, it added.

Several pressure groups are concerned to see that the threat does not become a hollow one, particularly in view of the growing importance of private insurance in Britain as all political parties accept the increasing difficulty of financing health care through the National Health Service.

The Royal Society is already planning to hold a meeting jointly with the Institute of Actuaries next summer on the topics of genetic screening and the insurance industry.

DAVID DICKSON London 